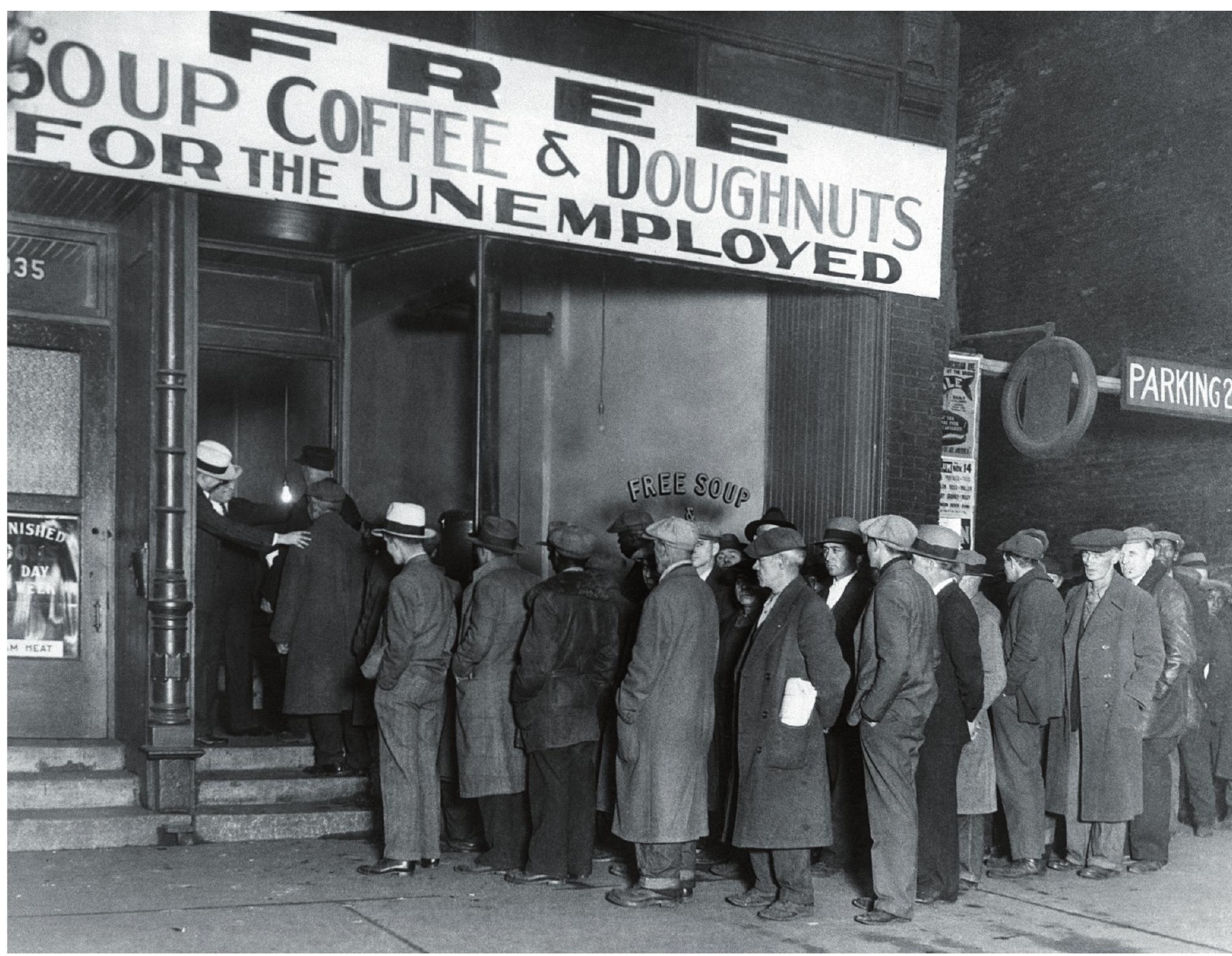

\title{
How the next recession could save lives
}

Death rates have dropped during past economic downturns, even as many health trends have worsened. Researchers are scrambling to decipher lessons before the next big recession.

\author{
BY LYNNE PEEPLES
}

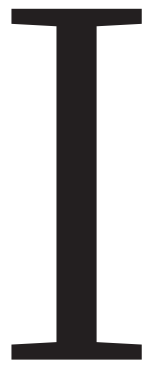

n 1922, a pair of sociologists at New York's Columbia University were poring over 50 years of US economic and mortality data, when they noticed a surprising result. Lean times in the country's history didn't correspond with more deaths, as they expected. In fact, the opposite was true. More people - babies included — died when the economy prospered ${ }^{1}$.

William Ogburn and Dorothy Thomas were sceptical enough to delve further. Would accounting for a possible lag in time between the downturn and the rise in deaths change the outcome? Or perhaps deaths had simply been recorded more rigorously during boom times? No, and no. Their peculiar finding seemed to hold.

About a decade later, data from the Great Depression, which hobbled the US economy for much of the 1930s, pointed to a similar conclusion" ${ }^{2}$ "After several years of severe economic stress, the

Soup kitchens sprang up around the United States at the onset of the Great Depression in the 1930s, including this one in Chicago, Illinois, run by notorious gangster Al Capone. 
gross death rate has attained the lowest level on record," wrote Edgar Sydenstricker, a social epidemiologist with the US Public Health Service, in 1933.

Even numbers from the global financial crisis of the late 2000s follow suit. José Tapia Granados, a health economist at Drexel University in Philadelphia, Pennsylvania, has calculated that death rates in Europe dropped faster during this downturn, known as the Great Recession, than before the crisis hit ${ }^{3}$. The trend held even in his birth country of Spain ${ }^{4}$, where unemployment topped $20 \%$.

"Everyone was expecting a strong increase in mortality. Again, it was the opposite," he says. Now he calls the link between recessions and lowered death rates, "almost as strong as the evidence that cigarette smoking is bad for health".

And yet, no one is quite ready to toast economic crises as a boon to public health. "If that were really true, then why don't we just recommend recessions?" says Ralph Catalano, a public-health researcher at the University of California, Berkeley. He and other scholars point to data showing clear negative consequences for individuals facing financial hardships, from stress-induced chronic diseases to mental-health problems.

Small salubrious effects spread among the majority of people could be masking a significant decline in health among the few - and a deepening of health inequities, warn some social scientists. Suicide rates, for example, usually seem to rise when the economy falls. And the opioid epidemic in the United States has caused particular harm in the populations most affected by the financial crisis. As leading causes of death have shifted there and elsewhere in the world - with greater contributions now from drug overdoses and cancer - signs are also emerging that the historical pattern between mortality and economic cycles has weakened in the past two to three decades.

A decade since the start of the Great Recession, and nearly 90 years after the onset of the Great Depression, researchers continue to debate how the economy affects public health. Meanwhile, lessons are emerging that could help to steer policymakers as they brace for the next crash, one that leading economists now predict could strike by the end of this year.

"Is a booming economy really good for people or bad for people? The answer, of course, is yes," says Harold Pollack, a social-policy and publichealth specialist at the University of Chicago in Illinois. "What we have to do is understand the ways it is protective or harmful. And then determine how we can maximize the protective dimension and minimize the harmful"

\section{SILVER LININGS}

Christopher Ruhm has spent the past two decades investigating the links between downturns and health. When he started his research, he wasn't aware of the early-twentieth-century literature. That work had been generally forgotten, he says, because it "didn't fit the obvious narrative".

He began by plugging data from more than a century of US history into a complex statistical model. Then, like his pre-Depression counterparts, he thought he had made an error. "So, I started looking at the raw data," says Ruhm, an economist at the University of Virginia in Charlottesville. "But it wasn't some programming mistake; it was real." In fact, he and others replicated the finding - in different situations, in different time periods, in different countries. In every case, Ruhm notes, the health of a majority of people improved, while the health of a minority declined.

There are many potential contributors. One of the more predictable perks of a poor economy is fewer job-related accidents ${ }^{5}$. The mostexperienced workers are the ones most likely to keep their jobs during a recession, and slower production can allow for more attention to safety.

People also tend to drive less, which translates to fewer traffic accidents $^{6}$. And fewer vehicles on the road might also help to explain why air quality is better?. "When employment pops up, so do things related to pollution - commerce, industry, trucks on the road," says Mary Davis, an environmental-policy specialist at Tufts University in Medford, Massachusetts. The air-quality connection might also help explain why studies have also linked recessions to reduced cardiovascular and respiratory problems, as well as infant mortality.

Researchers have suggested other explanations. In addition to dirty air, cardiovascular issues are known to be exacerbated by stress, a poor diet, lack of exercise, drinking alcohol and smoking tobacco. Working less and having less money to spend could translate into more sleep, exercise and home-cooked meals, as well as less job-related stress and less money for pints of beer and cigarettes. There is some evidence that this logic plays out. Based on data from 1987 through to 2000, Ruhm found that smoking and excess weight declined during economic downturns, whereas leisuretime physical activity increased ${ }^{8}$. When Iceland's economy crashed in 2008, and the price of imported goods such as tobacco and alcohol rose, citizens consumed fewer of those products ${ }^{9}$. And US data from 1977 to 2008 showed that a husband's unemployment reduced how much alcohol his wife drank, on average, irrespective of her own employment status ${ }^{10}$. Even people who fear job loss, but remain fully employed, Catalano's research suggests, might still cut back on alcohol to seem a more indispensable employee ${ }^{11}$.

Yet studies have shown that people cope with economic insecurity in unhealthy ways, too. Although overall alcohol consumption decreased during US recessions in the 1980s and 1990s, binge drinking increased ${ }^{12}$. And researchers have found that opioid prescription rates during the Great Recession were highest in the south, Appalachia and rural western United States, some of the areas hardest hit.

"If people are depressed and stressed out, they might drink more, use tobacco more, or eat more comfort foods," says Sarah Burgard, a sociologist at the University of Michigan in Ann Arbor.

\section{DOWNTURNS' DOWNSIDES}

Burgard and Ruhm met in Ann Arbor, in October 2004. They were two of a couple of dozen economists, epidemiologists, sociologists and psychologists tapped to co-author a book on the health effects of social and economic - or 'non-health' - policies. The meeting had brought them together to share initial outlines for their chapters. But a divide soon appeared. As fellow participants proposed disparate takes on how a failing economy helps or harms health, some people grew "red and heated",

\section{"Is a booming economy really good for people or bad for people?"} Burgard recalls.

"Economists were really pushing hard on positive effects. But the occupational psychologists and sociologists in the audience were not having it," she says.

She knew that many negative effects could stem from unemployment, income shock and vanished investments. A study published last March linked the Great Recession with high blood pressure and high blood glucose levels in Americans ${ }^{13}$. Losing a job when a business closed increased the odds of developing a stressrelated condition such as hypertension, arthritis, diabetes or psychiatric disorders, according to a study ${ }^{14}$ published in 2009. And the effects might linger.

A person in the United States who lost their job - and, thereby, their employer's health insurance - might seek fewer prescription refills or preventive screenings, and that could lead to greater complications from diabetes or a higher risk of late-stage cancers years later ${ }^{15}$. Or the chronic stress of unemployment and a thin wallet might take its toll on the body - increasing inflammation, reducing immunity and altering levels of hormones that are crucial to keep the body functioning normally.

The Great Recession has also been tied to outbreaks of infectious disease. The abandonment of home swimming pools during the foreclosures that followed the crisis helped to trigger a nearly threefold rise in cases of mosquito-borne West Nile virus in Kern County, California ${ }^{16}$. And part of Greece's response to the economic downturn - cutting back on mosquito spraying and needle-exchange programmes - resulted in a return of malaria ${ }^{17}$ and a doubling of HIV infections ${ }^{18}$.

These health consequences have not been evenly distributed across populations. In a study of European countries during the Great Recession, Kjetil van der Wel, a social scientist at Oslo Metropolitan University, found that health inequality increased by as much as $15 \%$ in countries that 


\section{The tenuous benefits of economic crises}

Researchers have long noted a counter-intuitive relationship between human health and the economy in developed nations. When recessions hit, the mortality rate drops faster than during boom years. But hiding in the data are many detrimental effects to mental health and the health of people low on the socio-economic ladder.

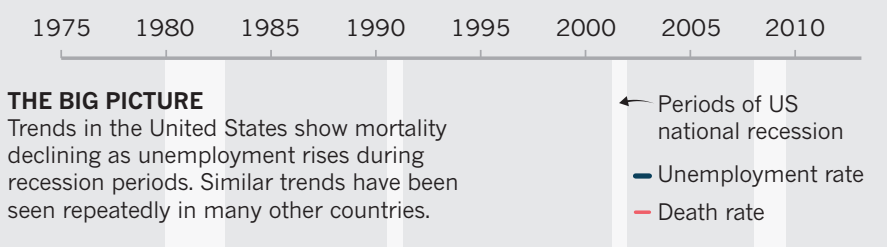
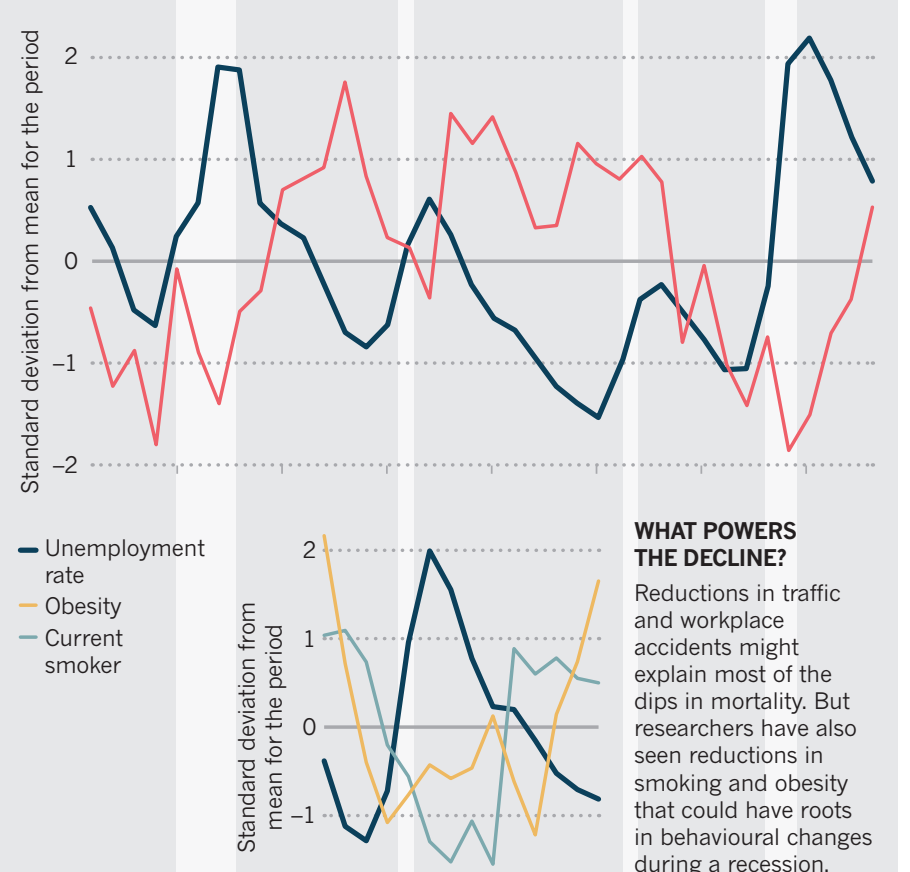

WHAT POWERS THE DECLINE?

Reductions in traffic and workplace accidents might explain most of the dips in mortality. But researchers have also seen reductions in smoking and obesity that could have roots in behavioural changes during a recession.

\section{SAFETY NETS HELP}

Suicide rates often increase as unemployment does, but public spending on social programmes can soften the blow. Spain spent relatively little on social protections during the 1990s, and political and economic turmoil coincided with a rising suicide rate. Sweden, by contrast, spent about four times as much, and achieved a steady drop.

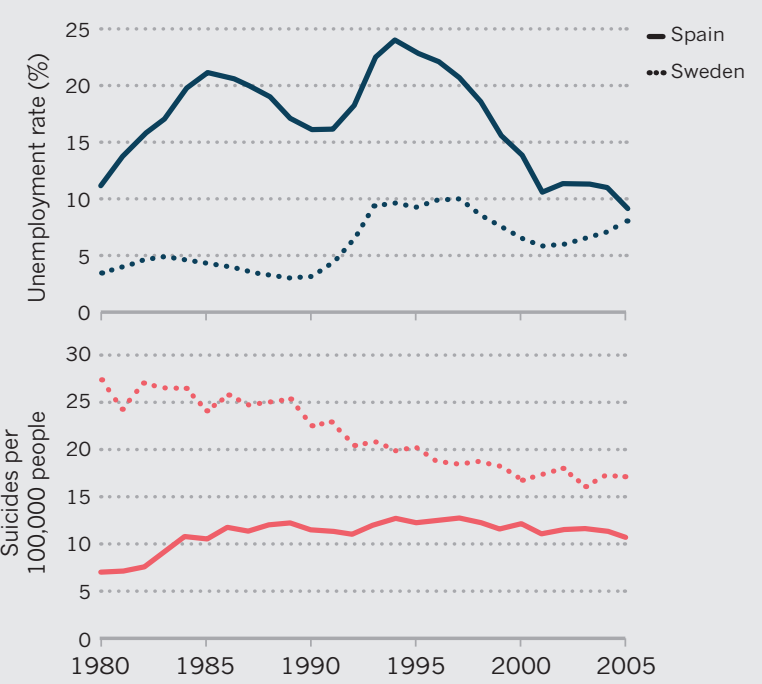

experienced a severe drop in gross domestic product along with cuts to government-funded social programmes and other austerity measures ${ }^{19}$.

And most of the data available, whether showing positive or negative effects, come from the developed world. Much less is known about the impacts of recessions in poor and developing countries.

Social scientists and epidemiologists are beginning to find more common ground, especially in the possibility that losing a job might be bad for an individual's health, whereas a declining economy could still be good, on average, for a population's physical health - although not necessarily mental health. Burgard left the Ann Arbor meeting intrigued enough to read the studies by Ruhm and other economists, as well as the papers dating back to the 1920s and 1930s.

"That was a big revelation," she says. "The conclusions we were drawing from different research perspectives can actually coexist.”

\section{DRIVING DESPAIR}

In president Franklin D. Roosevelt's inaugural address in 1933, he told the US people that the nation's "common difficulties" at the time concerned "only material things".

He wasn't entirely correct. Everyone seems to agree that a poor economy is bad for mental health. And that can be linked to more than just money and material things, suggests Burgard. Someone who becomes unemployed can also face the loss of a major social role that once provided a sense of purpose and identity. And losing a home can undermine people's sense of self-worth. "It's not just a hit to your credit rating," she says. Burgard has linked perceived job insecurity to depression and anxiety even in those who avoided unemployment in the Great Recession ${ }^{20}$.

Across the decades, suicide rates have generally risen during recessions (see 'The tenuous benefits of economic crises'). Sydenstricker noted this in the 1930s, and it has continued. David Stuckler, a political economist and sociologist at Bocconi University in Milan, Italy, estimates that the United States saw 4,750 more suicides between 2007 and 2010 than would have been expected given pre-recession trends ${ }^{21}$. Although some evidence suggests that economic fluctuations might not be the strongest contributing factor.

Suicide and overdose rates continued to rise in the United States even as the economy rebounded from the recession, for example ${ }^{22}$. Stuckler suspects that this boom-time bump has been driven by a long-term upwards trend linked to factors such as the availability of guns and opioids.

The US Centers for Disease Control and Prevention announced last November that 2017 was the third straight year of decline in US life expectancy - despite its continued ascent in other high-income coun- $\stackrel{0}{\circ}$ tries and despite the United States' oversized spending on health care ${ }^{23}$.

One explanation could be that the United States also spends the least on social safety nets, relative to those healthier countries. "If you underspend in social services and overspend in medical services, that's associated over decades with worse health outcomes," says Elizabeth Bradley, a global-health scholar and president of Vassar College in Poughkeepsie, New York.

When they faced major recessions, Sweden and Finland invested heavily in worker retraining and other programmes to improve people's chances of getting jobs. As a result, these countries escaped rises in suicides, says Stuckler. "These programmes help people stay plugged in," he says. "They give people a reason to get out of bed in the morning."

\section{HEALTH MAKES WEALTH}

Health-promoting investments, such as those made by Sweden and Finland during recessions, might also help an economy to bounce back by boosting productivity and reducing the burden on welfare. An analy$\mathrm{sis}^{24}$ of Denmark's active labour market programmes calculated savings equal to about US\$47,000 per worker between 1995 and 2005.

A similar connection emerged during the New Deal, the social and economic programmes championed by Roosevelt between 1933 and 1938, and widely credited with pulling the United States out of the Great Depression. The initiatives included housing, nutrition and health-care support. Stuckler estimates that for every $\$ 100$ in New Deal spending 


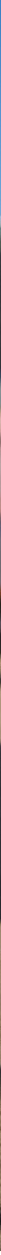

per capita, there was a decline in pneumonia deaths of 18 per 100,00 people, a reduction in infant mortality of 18 per 1,000 live births and a drop in suicides of 4 per 100,000 people. More generally, according to Stuckler's cal$\frac{x}{2}$ culations, investing $\$ 1$ in public-health programmes can yield as much as $\$ 3$ in economic growth ${ }^{25}$.

International creditors might have been using different calculations when they implored countries to implement harsh austerity measures during the 1997 Asian financial crisis. The result was widespread hunger and infectious-disease outbreaks in Thailand and Indonesia; Malaysia, which resisted the creditors' call, survived the crisis with its public health relatively unscathed. Greece, too, implemented an austerity plan in 2010 in an attempt to resolve its enormous debt. The more spending the country cut, the more its economy shrank. And health plummeted, with the greatest impacts in those most reliant on safety-net programmes: young and elderly people.

Health problems that arise during recessions, Stuckler suggests, might have less to do with the recession itself and more to do with the policy response. "Cutting public health is a false economy," he says. "Unfortunately, it is a soft, easy target for politicians."

Economists now predict another impending recession, which could widen the gap between wealthy and poor, and healthy and sick. Yet researchers hope that the next crash will lend more data and help to understand the nuanced links between economic cycles and health. Is the growing contribution of cancer to modern mortality - and the increasingly unaffordable price of effective treatments - dampening the historically downwards trend in deaths during downturns? What social safety nets and other policies - such as those that affect access to alcohol, drugs or guns - are most protective for public health? And how might leaders leverage the potential of communities working together during a crisis?
Such insights might also hint at ways to improve health in economic boom times, by reducing dangers associated with over-consumption, traffic accidents or pollution. The ultimate goal, notes Stuckler, is to identify and prevent avoidable suffering.

"There has been a lot of intellectual infighting in the debate over whether economic crashes are good or bad for health," he says. "Now, the key question is how can we protect people who are put in harm's way by these crises. What choices do we have?"

Lynne Peeples is a science journalist in Seattle, Washington.

1. Ogburn, W. F. \& Thomas, D. S. J. Am. Stat. Assoc. 18, 324-340 (1922).

2. Sydenstricker, E. Milbank Mem. Fund Q. Bull. 11, 273-280 (1933).

3. Granados, J. A. T. \& lonides, E. L. Health Econ. 26, e219-e235 (2017).

4. Regidor, E. et al. Lancet 388, 2642-2652 (2016).

5. de la Fuente, V. S. et al. J. Safety Res. 48, 77-85 (2014).

6. Ruhm, C. Q. J. Econ. 115, 617-650 (2000).

7. Davis, M. E. Am. J. Publ. Health 102, 1951-1956 (2012)

8. Ruhm, C. J. J. Health Econ. 24, 341-363 (2005).

9. Ásgeirsdóttir, T. L., Corman, H., Noonan, K., Ólafsdóttir, P. \& Reichman, N. E. Econ. Hum. Biol. 13, 1-19 (2014).

10. Arcaya, M., Glymour, M. M., Christakis, N. A., Kawachi, I. \& Subramanian, S. V. Soc. Sci. Med. 110, 89-95 (2014).

11.Catalano, R., Dooley, D., Wilson, G. \& Hough, R. J. Health Soc. Behav. 34, 215-225 (1993).

12.Dee, T. S. Health Econ. 10, 257-270 (2001).

13. Seeman, T. et al. Proc. Natl Acad. Sci. USA 115, 3296-3301 (2018)

14. Strully, K. W. Demography 46, 221-246 (2009).

15. Mortensen, K. \& Chen, J. JAMA Intern. Med. 173, 315-317 (2013).

16. Reisen, W. K. et al. J. Med. Entomol. 45, 494-508 (2008)

17. Kondilis, E. et al. Am. J. Publ. Health 103, 973-979 (2013).

18. Global Burden of Disease 2016 Greece Collaborators Lancet Publ. Health 3, PE395E406 (2018).

19. van der Wel, K., Saltkjel, T., Chen, W.-H., Dahl, E. \& Halvorsen, K. Sociol. Health Illness 40, 750-768 (2018).

20. Burgard, S. A., Kalousova, L. \& Seefeldt, K. S. J. Occup. Environ. Med. 54, 1101-1106 (2012).

21. Reeves, A. et al. Lancet 380, 1813-1814 (2012).

22. Hedegaard, H., Miniño, A. M. \& Warner, M. NCHS Data Brief number 329 (2018). 23. Murphy, S. L. et al. NCHS Data Brief number 328 (2018)

24.Jespersen, S. T., Munch, J. R. \& Skipper, L. Lab. Econ. 15, 859-884 (2008).

25. Reeves, A., Basu, S., McKee, M., Meissner, C. \& Stuckler, D. Glob. Health 9, 43 (2013) 